Raphael Cohen-Almagor

This is an Accepted Manuscript of an article published by Taylor \& Francis in British Journal of Middle Eastern Studies on 02 December 2016, available online: http://wwww.tandfonline.com/10.1080/13530194.2016.1258543

\title{
Discrimination against Jewish Women in Halacha (Jewish Law) and in Israel Introduction
}

Israel was established three years after the end of World War II. The raison d'être was to secure a safe haven for Jews. After the horrors of the Holocaust, there was a full realization that there should be a home for the Jewish people. Israel should facilitate the necessary mechanisms to make it a home for all Jews, native and immigrants. The State's founding establishment wanted Israel to be a democratic Jewish home. Notwithstanding the inherent tensions between Judaism and liberal democracy, ${ }^{1}$ the Jewish population in Israel tended and tends to believe that it is possible to have a state that is both Jewish and democratic. In the 2013 Israel Democracy Index, 28.2 percent of respondents said it is preferable in all cases to adhere to the precepts of Jewish religious law, Halacha, in the event of conflict between democracy and Halacha. $^{2}$ People were further asked which part of Israel's definition as a Jewish democratic state is "more important to you personally?" 32.3 percent answered that the Jewish part is more important; 29.2 percent said that the democratic character is more important, while 37 percent thought that both are equally important. ${ }^{3}$ However,

\footnotetext{
${ }^{1}$ R. Cohen-Almagor, "Avoiding the Destruction of the Third Temple: Separating State and Religion", in Yossi Goldstein (ed.), Religion Nationalism: The Struggle for Modern Jewish Identity, An Interdisciplinary Annual (Ariel: Ariel University, 2014): 170-189.

2 Tamar Hermann et al., The Israeli Democracy Index 2013 (Jerusalem: Israel Democracy Institute, 2013): 150.

${ }^{3}$ Tamar Hermann et al., The Israeli Democracy Index 2013, p. 139.
} 
the reconciliation of democratic values with Jewish values is hard, if not impossible, to achieve.

When Israel was established, its leaders were, influenced by the socialist tradition. They were not committed to liberal ideas. They wanted to create a state based on Jewish and socialist values and whose procedures were democratic. With time, due to political constraints (the Soviet Union preferred to align itself with the Arab world, not with Israel), Israeli leaders -- who always sought powerful allies to secure its destiny -- changed their political orientation from East to West and slowly grew to adopt liberal values. But their commitment to liberalism was not as fundamental as their commitment to democracy. The underlying values of Israel are a mix of socialism, liberalism and Jewish values. While liberalism is built on the motto of 'Live and Let Live', Judaism is built on a belief in God whose dictates administer how we all should live. All Jews are in the same boat, and therefore the liberal maxim of 'Live and Let Live' is unattainable: The non-believer might rock the boat, capsizing us into the deep and turbulent water. Against the liberal values of autonomy, personal development, individualism and self-government, there is the deep Jewish belief in shared communality, in shared destiny.

On the eve of Israel Independence Day 2016, the Israeli population was $8,522,000 .^{4}$ Some twenty per cent of the Jewish people in Israel are religious people, many of whom may prefer theocracy over democracy; some twenty per cent of the Israeli people are Palestinian-Arabs, who do not endorse the Zionist ethos of the State - the idea that Israel is the home of the Jewish people; and further twenty per cent of Israelis had arrived from the Soviet Union. Most of the Russian immigrants are secular

\footnotetext{
4 Latest Population Statistics for Israel, Jewish Virtual Library (May 2016), http://www.jewishvirtuallibrary.org/jsource/Society_\&_Culture/newpop.html
} 
or agnostic. ${ }^{5}$ A third of them are not Jewish. ${ }^{6}$ This mixture sets the scene for the understanding of Israel and its complex state of human rights.

This article focuses on the status of women. It is argued that because Jewish Law (Halacha) discriminates against women, there is quite a mountain to climb to secure gender equality in Israel. It is further argued that Orthodox Judaism and liberal democracy are in continuous conflict, and that gender equality rights directly clash with religious norms. As Jewish religion is unyielding and coercive, egalitarianism is still in the making.

This article is based on several underlying premises and concepts:

$\S$ Freedom v. coercion: People would like to lead their lives as free and autonomous human beings. Thus, coercion is foreign to us humans, offensive to our sensibilities and leads to an increased sense of alienation and resentment.

$\S$ Gender equality: Men and women should enjoy equal human and civil rights. Men are not inferior to women. Women are not inferior to men. ${ }^{7}$ Granted that men and women are biologically different, biology should not lead to a differentiation of rights and liberties. Countries that perceived biology as the dictating factor were/are racist countries.

\footnotetext{
5 Angelina E. Theodorou, "Israeli Jews from the former Soviet Union are more secular, less religiously observant", Pew Research (30 March 2016),

HTTP://WWW.PEWRESEARCH.ORG/FACT-TANK/2016/03/30/ISRAELI-JEWS-FROM-THEFORMER-SOVIET-UNION-ARE-MORE-SECULAR-LESS-RELIGIOUSLY-OBSERVANT/

${ }^{6}$ Tamar Horowitz, "The Absorption of Immigrants from the Former Soviet Union," in R. CohenAlmagor (ed.), Israeli Democracy at the Crossroads (London: Routledge, 2005): 117-136, at 119.

${ }^{7}$ Susan Moller Okin, "Feminism, Women's Human Rights, and Cultural Differences", Hypatia, Vol. 13, no. 2 (Spring 1998): 32-52.
} 
$\S$ Religion is a matter of personal choice, faith and belief. Because religion provides an all-encompassing framework for all issues, people should be free to take what is appealing to them and reject aspects that are less appealing.

$\S$ Consequently, freedom of religion, and freedom from religion are equally important. Both are matters of personal choice. Citizens in a democracy should enjoy the ability to choose one or the other. Each and every person should be allowed to choose her conception of the good, as she sees fit and appropriate for herself, as long as she does not harm others.

$\S$ Public v. private: A clear distinction has to be made between the communal character of the State, and personal matters. Personal matters are, by definition, personal. The State should limit its involvement in such matters to absolute minimum, and intervene only when there are significant countervailing public interests.

$\S$ Values: As Jews, as human beings, we uphold Hillel's postulate "What is hateful to you do not do unto your fellow people". ${ }^{8}$ As liberals, we uphold John Stuart Mill's Harm Principle which holds that the only purpose for which power can be rightfully exercised over any member of the community, against her will, is to prevent harm to others. ${ }^{9}$ On this issue, Judaism and liberalism are in complete agreement.

\footnotetext{
${ }^{8}$ Hillel (Babylonian Talmud. Sabbath 31a).

9 J. S. Mill, Utilitarianism, Liberty, and Representative Government (London: J. M. Dent, 1948),

Everyman's edition, at 114 or On Liberty, http://www.utilitarianism.com/ol/three.html
} 
$\S$ Judaism is not one homogenous religion. Within it there are different strands, different interpretations of the Holy Scriptures, different understandings of the religious implications to leading our everyday life, e.g., Reform, Conservative, Orthodox, and Ultra-Orthodox.

These are the underpinning premises of this article. Section I explains the Halachic grounds for discrimination against women. Orthodox Judaism is chauvinistic and assigns different tasks to men and women, explaining that given the innate characteristics of men and women, these tasks are natural to them. Section II concerns the Israeli legal framework and the role of the family courts. Section III provides legal background on legislation and important Supreme Court rulings designed to promote equality between men and women, and aiming to counter the discriminatory Jewish Law. Section IV analyses inegalitarian manifestations of Orthodox Judaism in Israeli society today. While the reality in Israel is, thankfully for women, very different from the Halachic literature, and the spirit of the time has significantly changed to be more liberal, women have a long way to go in order to achieve gender equality.

\section{Discrimination against Women}

Jewish law, Halacha, does not perceive men and women as equal. Many of the halachot (dictates) stand in striking contradiction to present conceptions of basic human and civil rights. They do not have a place in a liberal democracy. Many of these halachot are not enforced in Israel as they seem ill-suited for present Israel. Still the overall culture and the structure that Jewish law creates are discriminatory against women, and plenty of inegalitarian dictates are still adhered to. 
Numerous passages make it clear that women are not in the same category as men. The hierarchy between men and women is clear. It manifested itself from the very first story of the creation. First it is written in Genesis that God created mankind in his own image, "in the image of God he created them; male and female he created them". ${ }^{10}$ But in the following chapter, qualification and clarification are provided. God did not create man and woman together. Instead, he created man and then he realized that Adam needed some assistance, "a helper suitable for him". ${ }^{11}$ Wild animals and all the birds in the sky were provided for the man but no suitable helper was found for Adam. Thus God decided to create a woman. In other words, the creation of the woman was decided after exhausting all other alternatives, and the woman's role on earth was decided from the start. Realizing that man needed help, God created a woman but he did not create her in the same way that he created Adam. God formed a man from the dust of the ground and breathed into his nostrils the breath of life, while the woman was created from the man. God caused the man to fall into a deep sleep and while he was sleeping, he took one of the man's ribs and made a woman from the rib. The man said, "This is now bone of my bones and flesh of my flesh; she shall be called 'woman,' for she was taken out of man." 12 And when the woman disobeyed the words of God and ate from the tree of the knowledge of good and evil, her punishment included "Your desire will be for your husband, and he will rule over you."13

Jewish law specifies the ways in which the wife must accept man's rule: she must tend to matters of the home and fulfil all the duties of practical daily life. She is obligated to serve her husband, revere him like a king and honour him exceedingly,

\footnotetext{
10 Genesis 1: 27.

11 Genesis 2: 18.

12 Genesis 2: 23.

13 Genesis 3: 16. Zangwill noted that that that was a punishment but not God's initial plan.
} 
obey him and do his will. She should "fill for him his cup, make ready his bed and wash his face, hands and feet". ${ }^{14} \mathrm{~A}$ woman should raise her man up. "When he is angry, she should calm him; when he is hurt, she should soothe him; when he has been done bad to, she should comfort him; when he is worried, she should restore him; when he is pressured, she should minimize requests; and cancel her will for her husband. She should diminish his sadness, his worry or anything which is hard on his heart". ${ }^{15}$ She must cook food for him and their children and provide clothing. ${ }^{16}$

Jewish law adopts double standards with regard to promiscuity: While a married man's adultery hardly carries any legal consequences, a married woman's adultery carries harsh consequences: she is to be immediately divorced with no monetary rights; she is prohibited from later marrying her former husband or the man with whom she had committed adultery, and any child resulting from the adulterous relationship is considered a bastard (mamzer) who is precluded from marrying within the Jewish community, except for a convert or another mamzer. ${ }^{17}$

Women are not called up to the Torah for an aliyah (the honour of being called to read from the Torah) and are not counted as part of a minyan (quorum of ten Jewish men required for communal religious services such as prayers). When the lives of a man and a woman are at risk, efforts should be made to save the man first because

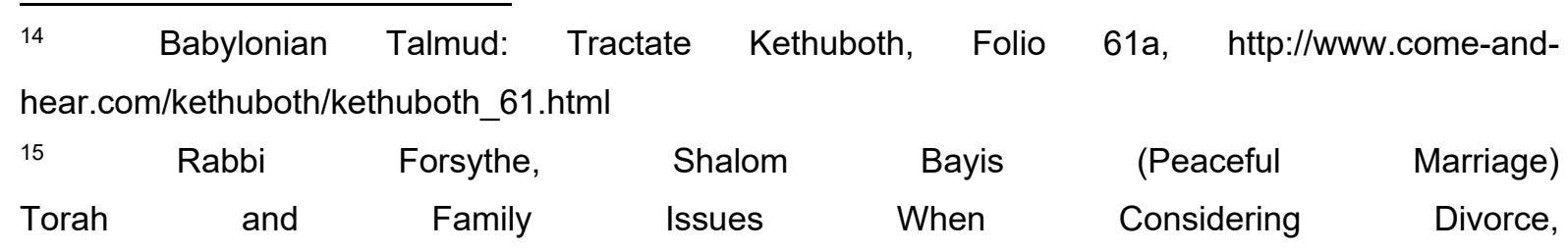
http://www.shemayisrael.com/rabbiforsythe/shalombayis/issues.htm

16 Babylonian Talmud: Tractate Yebamoth, Folio 63a, http://www.come-andhear.com/yebamoth/yebamoth_63.html; Bava Metzia 59, http://www.dafyomi.co.il/bmetzia/points/bmps-059.htm

17 Ruth Halperin-Kaddari, "Women, Religion and Multiculturalism in Israel", UCLA Journal of International Law and Foreign Affairs, Vol. 5, No. 2 (2000-2001): 349. 
the man is obligated to fulfil more commandments. Thus if a couple falls into a river and it is possible to save one of them, save the man. ${ }^{18}$ It is preferable to have sons rather than daughters. This is because daughters are more open to the charges of stubbornness and rebelliousness, and it is "supposed that her future be to stand in the way and entice men to sin". ${ }^{19}$ Thus it is better to have "a son, and not a daughter."20

To those who think that a daughter is a treasure, Tractate Sanhedrin ${ }^{21}$ provides an eye opener: "A daughter to a father is a false treasure, as because he is afraid of her, he does not sleep in the night. When she is a minor, perhaps she will be seduced. When she becomes of age, perhaps she will sin, when she becomes vigaros, perhaps she will not marry. If she is married, perhaps she will have no children. And when she becomes old, perhaps she will become a witch?"22 Any way you look at it, girls are bad news, a constant cause for worry. Thus the rabbis said: The world cannot be without males and females; however "happy are those who have male children, etc. And if because there is written 'Thou shalt not bring worry in thy heart,' as such has killed strong men." 23

18 Daat Emet, The Status of Women in Halacha, http://www.daatemet.org/articles/article.cfm?article_id=120\&lang=en

19 Tractate Sanhedrin, Chapter VIII, http://www.jewishvirtuallibrary.org/jsource/Talmud/sanhedrin8.html

20 Tractate Sanhedrin, Chapter VIII, Ibid

21 The tractate of Sanhedrin is part of the Talmud that details the laws applicable to the hierarchal Jewish judicial system, as well as the various penalties - monetary, corporeal and capital - at its disposal.

22

Tractate

Sanhedrin

Chapter

$\mathrm{XI}$ http://www.jewishvirtuallibrary.org/jsource/Talmud/sanhedrin11.html

23 Tractate Sanhedrin Chapter XI, Ibid 
The Mishnah in Berakhot (3:3) states: "Women, slaves and minors are exempt from Kriat Shema ${ }^{24}$ and from Tefillin". ${ }^{25}$ This trio of women, slaves and children appears quite frequently and suggests the level of trust that women should be conferred with, similar to the level we bestow on slaves and children. "Women, slaves, and small children are exempt from the use of the sukkah". ${ }^{26}$ Women by themselves or slaves by themselves invite one another to say grace, but women, slaves and minors may not invite one another, even if they wish to. From this we learn that women join to form a zimun (eating together) by themselves. ${ }^{27}$ Women constitute a category of their own, separate from men who may invite whoever they wish.

The Halachic view of women is not very kind. Women are lazy and are prone to cry. ${ }^{28}$ Time and again it is reiterated that women cannot be trusted. They lack good sense of judgment and open to temptations. Only a complete fool of a husband will ask and then follow his wife's advice: "Anyone who follows his wife's counsel falls to Gehinom" (hell). ${ }^{29}$ The husband should honour and respect his wife because she

\footnotetext{
${ }^{24}$ Kriat Shemais a very important statement, an affirmation of Judaism and a declaration of faith in one God. The obligation to recite Kriat Shema is separate from the obligation to pray. A Jew is obligated to say Shema twice a day, in the morning and in the evening. See Translation of The Shema, http://www.chabad.org/library/article_cdo/aid/706162/jewish/Translation.htm

${ }^{25}$ Tefillin (phylacteries) are a set of small black leather boxes containing scrolls of parchment inscribed with verses from the Torah and placed on the head and the arm. They are worn by Jewish men during weekday morning prayers. Their symbolic function is to remind Jews that God brought them from slavey in Egypt to freedom in Israel.

26 Jonathan Mishnah Sukkot, Chapter II, http://www.oceansidejc.org/sukkotmish/suk2.html. Sukkah is a temporary hut constructed for use during the week-long festival of Sukkot in which Jews celebrate the journey Jews travelled in the desert after they were freed from Egyptian slavery on their way to free, independent life in Israel.

${ }^{27}$ Medieval Sourcebook: Reciting the Grace after Meals: The Status of Jewish Women, from Berakhot, chap. 7, (NY: Fordham University, November 1998), http://www.fordham.edu/halsall/source/jewishwomen-grace.asp

${ }^{28}$ Bava Metzia 59, http://www.dafyomi.co.il/bmetzia/points/bm-ps-059.htm

${ }^{29}$ Bava Metzia 59, http://www.dafyomi.co.il/bmetzia/points/bm-ps-059.htm
} 
serves and obeys him, and he has an interest that she will continue doing just that. "She does him good, and not harm, all the days of her life. She seeks wool and flax, and works with willing hands. She is like the ships of the merchant; she brings her food from afar. She rises while it is yet night and provides food for her household and portions for her maidens."30

However, men should never forget women's flaws. Women are talkative and unreliable. Thus it is better to check on them, and avoid putting them in situations where they might be tempted. The Halacha instructs that women, slaves, and minors should not to search for chametz ${ }^{31}$ because they are too lazy to do this properly. Tractate Pesachim ${ }^{32}$ 4b says: "In any case, were checking for chametz from the Torah, we would not believe women because it is great effort and requires precision, as is evident from the Jerusalem Talmud, ${ }^{33}$ which explains that women are lazy." We should not trust women about anything which involves a great deal of bother. ${ }^{34}$ Women, slaves and minors should be under close scrutiny.

\footnotetext{
${ }^{30}$ Proverbs 31:12-15. On the husband's obligations toward his wife and his rights in respect of her, see Husband and Wife, Jewish Virtual Library,
} http://www.jewishvirtuallibrary.org/jsource/judaica/ejud_0002_0009_0_09341.html

${ }^{31}$ Chametz are leavened foods that are forbidden on the Jewish holiday of Passover.

32 This part of the Talmud details the regulations concerning the meal on the eve of Passover and the four cups of wine to be drunk with the meal.

33 The Jerusalem Talmud also known as the Palestinian Talmud or Talmuda de-Eretz Yisrael (Talmud of the Land of Israel), is a collection of Rabbinic notes on the second-century Jewish oral tradition known as the Mishnah.

34 Daat Emet, The Status of Women in Halacha, http://www.daatemet.org/articles/article.cfm?article_id=120\&lang=en 
The unreliability of women is a reoccurring theme. A man may be alone with two women, e.g. his mother and his daughter, and he may sleep with them in immediate bodily contact but when they grow up they must sleep in their garments. This is because "women are temperamentally light-headed". ${ }^{35}$ And, of course, one should not trust those who cannot keep their thoughts to themselves. Women according to Halacha are not familiar with the slogan "Silence Is Golden". They talk far too much. "Ten kabs (an ancient Hebrew measure) of gossip descended to the world: nine were taken by women". ${ }^{36}$ Women are of unstable temperament. ${ }^{37}$

With such a view of women, no wonder Jewish men pray every morning ("The morning blessings") "Blessed be He who made me not a woman."38 A woman, in her baseness and inferiority, says, "Blessed be He who made me according to His will."39

According to halacha, in the public sphere, women cannot serve in power positions. They are excluded from the executive and judicial offices as well as from the spiritual sphere. The Torah dictates "be sure to appoint over you a king", ${ }^{40}$ not a

\footnotetext{
${ }^{35}$ The Babylonian Talmud, Kiddushin 70b, http://juchre.org/talmud/kiddushin/kiddushin4.htm\#70b

${ }^{36}$ The Babylonian Talmud, Kiddushin 49a, http://juchre.org/talmud/kiddushin/kiddushin3.htm\#49a

37 Babylonian Talmud: Tractate Shabbath, Folio 33a, http://www.come-andhear.com/shabbath/shabbath_33.html

${ }^{38}$ Rabbi Eliezer Melamed, "Birkot HaShachar - The Morning Blessings", http://www.yeshiva.co/midrash/shiur.asp?id=28083; Josh Halpern, "Should Men Thank God They Were Not Born Women?", Forward (August 26, 2013), http://forward.com/articles/182947/shouldmen-thank-god-they-were-not-born-women/

39 Josh Halpern, "Should Men Thank God They Were Not Born Women?".

${ }^{40}$ Deuteronomy 17.
} 
queen. ${ }^{41}$ Women are invalid to serve as judges. ${ }^{42}$ Women are invalid witnesses. ${ }^{43}$ They cannot give evidence. ${ }^{44}$ In the spiritual sphere, as noted above, women cannot read from the torah in public. This is in order to protect public honour. ${ }^{45}$ In the private sphere, women are always under the authority of men. First, under the authority of their fathers, and once they wed they are subject to their husbands. ${ }^{46}$

Women are discouraged from pursuing higher education or religious pursuits. This is because women have frivolous minds ${ }^{47}$ and also because they have important roles to fulfil in the home as wives and mothers. ${ }^{48}$ As men are physiologically and biologically incapable of carrying out these important tasks, they must be carried out by women. And as these tasks are very demanding, women are incapable of splitting

\footnotetext{
${ }^{41}$ Maimonides, Laws of Kings and Wars, http://halakhah.com/rst/kingsandwars.pdf
}

42 Shulchan Aruch/Choshen Mishpat/7, http://en.wikisource.org/wiki/Shulchan_Aruch/Choshen_Mishpat/7. Although Deborah led Israel as a judge. The opening Judges 4:4-5 says: "At that time Deborah, a prophetess, wife of Lappidoth, was judging Israel. She used to sit under the palm of Deborah between Ramah and Bethel in the hill country of Ephraim; and the Israelites came up to her for judgment."

${ }^{43}$ Deuteronomy 19:17.

44 Babylonian Talmud: Tractate Baba Kamma 88a, http://www.come-andhear.com/babakamma/babakamma_88.html

${ }^{45}$ The sages said: "a woman should not read from the Torah mipnei kevod hatzibbur-out of respect for the congregation." See Natalie Bergner, "Qeri'at ha-Torah: Public Torah Reading", Women of the Wall, http://womenofthewall.org.il/qeriat-ha-torah-public-torah-reading/

46 Babylonian Talmud: Tractate Kethuboth 48a, http://www.come-andhear.com/kethuboth/kethuboth_48.html. For further discussion, see Rachel Biale, Women and Jewish Law: The Essential Texts, Their History, and Their Relevance for Today (NY: Schocken, 1995).

47 Tirzah Meacham, "Legal-Religious Status of the Jewish Female", Jewish Women Encyclopedia, http://jwa.org/encyclopedia/article/legal-religious-status-of-jewish-female

${ }^{48}$ The Role of Women, Judaism 101, http://www.jewfaq.org/women.htm 
their time between the home and pursuits of higher education or religion to which they are ill-equipped; thus success in them would demand from them more effort, at the expense of caring for the home. Women must never neglect their husbands and children; thus the priorities are clear.

And who are women of merit? These are women who make their children go to the synagogue, learn Scripture and those who enable their husbands to attend the Beth Hamidrash (place of study Torah) to learn Mishnah. ${ }^{49}$ Women of merit are those who are waiting for their husbands until they return from the Beth Hamidrash ${ }^{50}$ and provide for them. Women are passive. Merit is not derived from their own activities but by providing to others, to men. Women, by definition, are givers, facilitators, enablers of what is truly important: the study of the Torah that is denied to them. Women accordingly could never achieve merit on their own right. They lack the necessary qualities of true scholars who could immerse themselves in the world of the Torah and delve into its complex teachings. Men and women are different and are blessed with different capabilities that supplement each other. Men need women to be able to immerse themselves in the tent of Torah. Women understand that the world is what it is because of God and the Torah, and men are those who perpetuate the belief and by their actions reaffirm the Godly existence that provides living. This halachic view explains that men are not superior to women. They are simply different, and have different and equally important tasks to fulfil. This is a very structural and organized view of life. Men have a clear place. Women have a clear place. Their combined effort is well appreciated by God.

\footnotetext{
${ }^{49}$ Collection of existing Jewish oral laws, traditions and traditional wisdom.

50 Babylonian Talmud: Tractate Berakoth, Folio 17a, http://www.come-andhear.com/berakoth/berakoth_17.html\#chapter_iii
} 
The common defence for maintaining this state of affairs holds that the exemptions that women are given from religious and other obligations are meant to foster women's ability to carry out their own tasks. ${ }^{51}$ The structured view of the world whereby men have certain roles, and women have certain roles, yields efficiency and constructive allocation of time for each gender to perform its duties. The underlying logic is of complimentary functionalism, not of discrimination. However, in the liberal tradition people should be left to decide what they want to do. It is not God, or his presumed directives that should guide us all, but rather we, human beings, guide and direct our own lives as we see fit, and we should be free to do so as long as we do not harm others. Tout court denial of choice undermines women's ability to lead what they may perceive as a meaningful way of life.

A further argument in defence of the "separate but equal" policy is that men and women have different qualities. Men, it is explained, are anatomically and spiritually external, and often view life from a more external viewpoint. Women, on the other hand, are anatomically and spiritually internal. They see the world from a more internal and holistic perspective. ${ }^{52}$ Women should not try to be men. God has assigned men for particular tasks, and women for other. Jewish women have their own mission, their own identity, their own worth. The Torah commands that "A man shall not wear a woman's garment," so equally it commands "A man's garment shall not be on a woman." ${ }^{53}$ Neither men nor women "carry out their G-d given tasks or achieve self-

\footnotetext{
51 Rabbi Mark Goldfeder, Defining Equality in Judaism, http://morethodoxy.org/2012/10/25/definingequality-in-judaism-by-rabbi-mark-goldfeder/

52 Meir Goldberg, Moral problems in Halacha: Women, http://truetorah.blogspot.com/2013/07/moralproblems-in-halacha-women-with.html

${ }^{53}$ Equal Rights, Sichos in English, http://www.sichosinenglish.org/essays/70.htm
} 
fulfillment by imitating the other. A woman has no reason to feel inferior to a man, and therefore she has no need to try to be as a man". ${ }^{54}$ Women thus should protest against those false claims about their discrimination and subordination to men which in essence rob them of their true identity and go against the will of God. Women's honour is inward, taking care of the house, of the men, of the children; providing a safe haven for the men who go about doing their God given tasks. Men recognize this and thus let them be in charge of household matters. ${ }^{55}$ In Israel, this also means that women often go to work to sponsor their families while their husbands memitim atzmam, "kill themselves" in the "tent of Torah".

Thus far for women stand in Halacha. Now let us turn to examine women status in Israeli society.

\section{Israeli Legal Framework and the Role of the Family Courts}

Israel formally inherited the Ottoman millet system in its modified form as applied under the British Mandatory regime,${ }^{56}$ when the Provisional Council of State enacted the Law and Administration Ordinance on 19 May 1948. The Ottoman millet system was employed to segregate and categorize colonial subjects into ethno-religious and tribal communities and to categorize them as first and foremost members of various religious groups, subjecting them to legal and institutional authority of their respective

\footnotetext{
${ }^{54} \mathrm{Ibid}$.

$\begin{array}{ccccccr}55 & \text { Rabbi } & \text { Forsythe, } & \text { Shalom } & \text { Bayis } & \text { (Peaceful } & \text { Marriage) } \\ \text { Torah } & \text { and } & \text { Family } & \text { Issues } & \text { When } & \text { Considering } & \text { Divorce, }\end{array}$
http://www.shemayisrael.com/rabbiforsythe/shalombayis/issues.htm; Bava Metzia 59a.

56 This in accordance with the Palestine Order in Council (1922) which ordered that "In Matters Of Personal Status Shall Be Exercised In Accordance With The Provisions Of This Part By The Courts Of The Religious Communities Established And Exercising Jurisdiction At The Date Of This Order". https://unispal.un.org/DPA/DPR/unispal.nsf/85255db800470aa485255d8b004e349a/c7aae196f41aa0 55052565f50054e656?OpenDocument
} 
faiths. ${ }^{57}$ In this way, different religious groups did not meddle in each other's affairs and, at the same time, the Ottoman rulers limited the power of each group through segregation. Muslims, Christians, and Jews were all recognized as self-governing units (or 'millets'), and allowed to impose restrictive religious laws on their own members. This was a group-based form of toleration, which did not recognize any principle of individual freedom of conscience. ${ }^{58}$

There are five officially recognized religions in Israel: Judaism (Orthodox), Islam (Sunni), Christianity (various denominations), Ba'hai and Druze. ${ }^{59}$ Each citizen may follow the religion into which s/he is born. The millet system remained effective during the British mandate and Israel modified it to its own purposes when the state was established. Israel first Prime Minister David Ben-Gurion feared fragmentation. He wished to maintain unity of the Zionist secular and religious elements of society. At the same time, he wished to demarcate cultural and religious disparities between the Arabs and the Jews. ${ }^{60}$ Aiming to establish a monolithic Zionist-Israeli-Jewish identity, Ben-Gurion in his role as Chairman of the Jewish Agency Executive Committee negotiated the identity of the newly established state with the religious-Orthodox community. In 1947, Ben-Gurion drafted a status quo agreement between the Jewish

\footnotetext{
57 Yuksel Sezgin, "The Israeli Millet System: Examining Legal Pluralism through Lenses of NationBuilding and Human Rights", Israel Law Review, Vol. 43 (2010): 631-633.

58 Will Kymlicka and Raphael Cohen-Almagor, "Ethnocultural Minorities in Liberal Democracies", in Maria Baghramian and Attracta Ingram (eds.), Pluralism: the philosophy and politics of diversity (London: Routledge, 2000): 228-250.

59 The Palestine Order in Council recognized eleven religious communities: Jewish, Muslim, and nine Christian denominations. Later the Israeli government added the Ba'hai, the Presbyterian Evangelical Church and the Druze.

${ }^{60}$ Efraim Karsh (ed.), Israel: the First Hundred Years: Volume I: Israel's Transition from Community to State (London: Routledge, 2014); Zaki Shalom, David Ben-Gurion, the State of Israel and the Arab World, 1949-1956 (Brighton and Portland: Sussex Academic Press, 2002); Shabtai Teveth, Ben-Gurion and the Palestinian Arabs: From Peace to War (Oxford: Oxford University Press, 1985).
} 
Agency and the World Organization of Agudat Israel, the hegemonic movement within the ultra-Orthodox Jewish public. The agreement provided the latter with certain guarantees on matters of matrimony, Shabbat, education, and kashrut ${ }^{61}$ in the Jewish state, once it is established. ${ }^{62}$ As part of this agreement, the Israeli government decided to grant the rabbinical courts jurisdiction over issues pertaining to personal status. Questions of marriage and divorce were perceived as central and more important than any other religious issue. Israeli leader, Golda Meir, declared that the survival of Israel and of the Jewish people depend, to a large extent, on their connection to Judaism. ${ }^{63}$ Consequently, such matters are determined in accordance with religious laws by the religious courts of different communities. ${ }^{64}$ The religious courts are granted exclusive jurisdiction over matters of marriage and divorce and concurrent jurisdiction with the civil courts regarding issues of maintenance and succession.

Thus, adopting the millet system to Israel served several prime purposes:

- Unity: maintaining unity of all the Jewish elements in society;

- Identity: Identify and crystalize the importance of Judaism in private matters;

- Inclusion: including all Jews within the arrangement notwithstanding whether they were secular or religious;

61 Set of Jewish religious dietary laws.

62 Daphne Barak-Erez, "Law and Religion under the Status Quo Model: Between Past Compromises and Constant Change," Cordozo Law Review, Vol. 30(6) (2009): 2495-2507; Ruth Lichtenstein, "The History of the 'Status Quo' Agreement", Hamodia (1 January 2014), http://hamodia.com/2013/12/31/history-status-quo-agreement/; Yaakov Malkin, Haim Cohen, Rachel Elior and Yehuda Bauer, Free Judaism and Religion in Israel (JERUSALEM: Free Judaism, 1998).

63 Nissim Rejwan, Israel in Search of Identity: Reading the Formative Years (Gainesville: University Press of Florida, 1999): 106.

64 Frances Raday, "Self-Determination and Minority Rights", Fordham International Law Journal, Vol. 26(3) (2002): 492. 
- Exclusion: excluding non-Jews from the rabbinical courts;

- Tolerance: projecting to all concerned, inside and outside Israel, that the Zionist state is tolerant of non-Jewish religions, granting them autonomy to handle their own affairs. Religious minorities need not conform to the Orthodox-Judaism way of life.

The majority of Israeli-Jews deeply appreciate religion yet they see it as a matter of personal choice, not as an overwhelming dictate from above. ${ }^{65}$ A 2010 survey of Israeli Jews over the age of 20 asked about self-definition. 8.8\% defined themselves as Haredi, $9.6 \%$ as religious, $13.7 \%$ as traditional/religious, $24.4 \%$ as traditional/not very religious, while $43.4 \%$ defined themselves as not religious or as secular. ${ }^{66}$ That means the majority of the Jewish population in Israel would object to certain religious practices they deem to be coercive. However, in Israel OrthodoxJudaism dictates the norms and customs of the state. Jewish law is patriarchal. It excludes women from full participation in the public sphere while subordinating women to male authority in the private sphere. In the courts, there are no women acting as rabbinical judges. ${ }^{67}$ The exclusion of marriage and divorce from women's constitutional right to equality has prompted many couples to prefer civil marriage over religious proceedings. In the absence of civil marriage in Israel, people need to go

\footnotetext{
${ }^{65}$ Raphael Cohen-Almagor, "Israel and International Human Rights", in Frederick P. Forsythe (ed.), Encyclopedia of Human Rights (New York: Oxford University Press, 2009), Vol. 3, pp. 247-257.

${ }^{66}$ Asher Cohen and Bernard Susser, "Religious Pressure Will Increase in the Future", Israel Studies Review, Vol. 27, No. 1 (Summer 2012): 16.

67 Diane Polan, "Toward a Theory of Law and Patriarchy", in David Kairys (ed.), The Politics of Law (Cambridge, MA: Basic Books, 1998). See also Frances Raday, "Religion, Multiculturalism and Equality: The Israeli Case", Israel Yearbook on Human Rights, Vol. 25 (1995): 193-210; Ruth HalperinKaddari, Women in Israel: A State of Their Own (Philadelphia: University of Pennsylvania Press, 2003).
} 
abroad if they wish to have non-religious ceremony. According to a recent poll, 78 percent of the Jewish population supports permitting civil unions or marriages. Among secular Jews, support is at 96 percent. ${ }^{68}$ Another poll shows that $70 \%$ of secular Jewish Israelis would prefer to have non-Orthodox weddings, if these were recognized by law. 69 of the Jewish public believe the Rabbinate's marriage monopoly distances Jews from Judaism, and only $14 \%$ believe it brings Jews closer to Judaism. ${ }^{70}$

Marriage and divorce are regulated by the law of the religious communities as applied by the religious courts. The Rabbinic Courts Jurisdiction Law (Marriage and Divorce) of 1953, which was passed after considerable controversy, provides that for Jews, who are either citizens or residents of Israel, matters of marriage and divorce are exclusively under the jurisdiction of the Rabbinic Courts, and that marriage and divorce should adhere to Halacha. ${ }^{71}$ Even before the passage of this law, the Rabbinic Courts had received a monopoly over matters of personal status under Article 5 of the Women's Equal Rights Law of 1951, which stated that the intent of the law was not to change the laws concerning permissions and prohibitions regarding marriage and divorce..$^{72}$

While the rabbinical courts retain sole authority on issuance of divorce decrees and on determining who is married and who is not, the civil courts are granted parallel jurisdiction in issues related to divorce such as child custody, alimony and division of

\footnotetext{
${ }^{68}$ Michael Mitchell, "Israeli Marriages: More Ottoman Than Jewish", Haaretz (2 July 2014).

69 The 2015 Israel Religion and State Index, "Marriage Freedom in Israel by the Numbers", Hiddush (2016), marriage.hiddush.org

$70 \mathrm{lbid}$.

${ }^{71}$ Raphael Cohen-Almagor, "Israeli Democracy, Religion and the Practice of Halizah in Jewish Law." UCLA Women's Law Journal, Vol. 11, No. 1 (Fall/Winter 2000): 45-65.

72 Daphna Sharfman, Living Without a Constitution (Armonk, NY: M.E. Sharpe, 1993): 78.
} 
property. The civil courts are operating in accordance with the 1995 Family Courts Law. All matters involving family members, from probate to business disputes are litigated in the Family Courts. Both the civil family courts and the rabbinical courts must apply Jewish law governing divorce unless an overriding norm is set in specific civil law provisions. The Supreme Court has ruled that the rabbinical courts must apply certain civil laws such as those guaranteeing equal property rights to women ${ }^{73}$ and those protecting personal privacy. ${ }^{74}$ In inheritance, the rabbinical court authority is contingent on the consent of all parties involved. If one party objects to consideration of the case in the rabbinical courts, the case will be referred to the family courts or to the inheritance registrar. ${ }^{75}$

\section{Women's Rights Legislation and Important Supreme Court Precedents} The Universal Declaration of Human Rights, 1948 [UDHR] is the normative foundation of human rights discourse. The historic context of the UDHR is similar to that of the establishment of the state of Israel. The preamble to the Declaration explains the need to protect human rights, in reference to the historic fact that "disregard and contempt for human rights have resulted in barbarous acts which have outraged the conscience of mankind". The two major international human rights legal instruments that derived from the UDHR are the International Covenant of Civil and Political Rights, 1966 [ICCPR] and the International Covenant of Economic, Social and Cultural Rights, 1966 [ICESCR], both were ratified by Israel in 1991. The government has also ratified the

\footnotetext{
${ }^{73}$ H.C.J. 1000/92 Bavli v Great Rabbinical Court (1994). The Court imposed on the rabbinical courts the obligation to abide by the principle of equality in the division of matrimonial property.

${ }^{74}$ H.C.J. 6650/04 Doe v District Rabbinical Court of Netanya (2006).

75 Daphna Hacker, "Religious tribunals in Democratic States: Lessons from the Israeli Rabbinical Courts", Journal of Law and Religion, Vol. 27(1) (2012): 78.
} 
1967 International Convention for Elimination of All Forms of Discrimination against Women, ${ }^{76}$ the 1981 Declaration on the Elimination of all Forms of Intolerance and of Discrimination Based on Religion or Belief, ${ }^{77}$ and the Convention on the Rights of the Child. ${ }^{78}$ These conventions have not been incorporated into Israeli domestic law, and are not directly enforceable by the courts. Furthermore, Israel expressed reservations regarding certain articles, e.g., those concerning appointment of women as judges of religious courts, and those concerning the elimination of discrimination in marriage and family matters. However, all authorities are required, as far as possible, to interpret legislation so as to avoid breach of Israel's international obligations. ${ }^{79}$

Israel has a strong constitutional tradition of civil and political human rights as constraints on the government's executive powers. The 1948 Declaration of Independence affirms that Israel will foster the development of the country for the benefit of all its inhabitants; that it will be based on the foundations of liberty, justice and peace; that it will ensure complete equality of social and political rights to all of its citizens irrespective of religion, race or sex, and that it will guarantee freedom of religion, conscience, language, education and culture. ${ }^{80}$ The Declaration was invoked

${ }^{76}$ International Convention for Elimination of All Forms of Discrimination against Women, 1967. http://www.ipu.org/PDF/publications/cedaw_en.pdf

${ }^{77}$ Declaration on the Elimination of all Forms of Intolerance and of Discrimination Based on Religion or Belief, 1981, http://www.un.org/documents/ga/res/36/a36r055.htm

${ }^{78}$ Convention on the Rights of the Child, Adopted and opened for signature, ratification and accession by General Assembly resolution 44/25 of 20 November 1989, entry into force 2 September 1990, http://www.ohchr.org/en/professionalinterest/pages/crc.aspx

${ }^{79}$ See F.H.Cr. 7048/97, Plonim v. Minister of Defence, P.D. 54 (1), 721. For further discussion, see Ruth Lapidot, Orna Ben-Naftali and Yuval Shani, The Obligation to Incorporate Human Rights Conventions into Israeli Law, Position Paper (Rishon LeZion, 2004) (Hebrew); Michal L. Allon, "Gender Inequity and Religion in Israel", in Mohammed M. Aman and Mary Jo Aman (eds.), The Middle East: New Order or Distorter? (Washington DC.: Westphalia Press, 2016): 265-278.

$80 \mathrm{http}: / /$ www.science.co.il//srael-Declaration-of-independence.asp 
by the courts to protect basic human rights in the absence of law. The Declaration has become the basic norm in Israeli law as it has established a symbiosis between the Jewish values of liberty, justice and peace and democratic values that are similarly these same values.

From the 1950s, women were entitled to maternity leave allowance paid by National Insurance, protection against dismissal during pregnancy and affordable childcare facilities, aimed to enable women to have secured employment while maintaining family life. ${ }^{81}$ In 1988, the Employment (Equal Opportunities) Law 57481988 was passed. The law dictates: "An employer shall not discriminate among his employees or among persons seeking employment on account of their sex, sexual tendencies, personal status or because of their age, race, religion, nationality, country of origin, views, party or duration of reserve service". ${ }^{82}$

In January 1974, the Spouses (Property Relations) Law (1973) came into effect. The Law introduced arrangements for regulating the property relations of spouses holding that in the absence of a "property agreement" to the contrary, the respective assets of the spouses are kept separate during the existence of the marriage. If the marriage comes to an end obligation arises between them or their heirs to balance equally the value of their aggregate property, excluding certain special items such as property which each possessed prior to the marriage or received by way of gift or inheritance during the marriage. ${ }^{83}$

81 Frances Raday, "Equality, Religion and Gender in Israel", Jewish Women's Archive, http://jwa.org/encyclopedia/article/equality-religion-and-gender-in-israel

82 Employment (Equal Opportunities) Law 5748-1988, http://www.ilo.org/wcmsp5/groups/public/--ed_protect/---protrav/---ilo_aids/documents/legaldocument/wcms_127881.pdf

83 Pinhas Shifman, "Property Relations between Spouses", Israel Law Review, Vol. 11 (1976): 110, http://papers.ssrn.com/sol3/papers.cfm?abstract_id=2619400 
In 1992, the Knesset legislated two Basic Laws to guarantee the basic rights and liberties of all citizens. Basic Law: Human Dignity and Liberty (1992) attempts to protect human dignity and freedom in order to establish the values of the State of Israel as a Jewish and democratic state. It maintains that a human being's property must not be harmed; that every person is entitled to the protection of her life, body and dignity, and that no person's freedom may be taken or restricted by unlawful arrest, imprisonment, or extradition, or in any other manner. ${ }^{84}$ In turn, Basic Law: Freedom of Occupation (1992) holds that every citizen or resident of the State is entitled to engage in any occupation, profession or line of work, and that every governmental agency must respect the freedom of occupation of every citizen or resident. The "constitutional revolution" of the enactment of these Basic Laws extended existing substantive principles in respect of the power of the Supreme Court to exercise judicial review. However, principles of equality and social justice, freedom of speech and religious freedom were omitted from the Basic Laws, and attempts to propose legislation that would guarantee full economic, social and cultural rights constitutionally to all Israeli citizens have not materialized till now. In her comments on a draft of this essay, former Justice of the Supreme Court Dalia Dorner wrote that the Knesset refusal to bolster and secure the Basic Laws by demanding a special majority for changing them makes the constitutional revolution meaningless. 
The Knesset has furthered protection of human rights in some fields by specific legislation, including the Prevention of Family Violence Law, 5751-1991, ${ }^{85}$ laws extending the prohibited grounds of discrimination in employment, ${ }^{86}$ and prohibiting discrimination in provision of goods and services; 87 an amendment strengthening the provisions of the Equality of Women's Rights Law, 5711-1951, a law on sexual harassment to defend human dignity, freedom and privacy and to promote equality between men and women, ${ }^{88}$ and a law on single-parent families that grants certain benefits to such parents, who are usually women. ${ }^{89}$.

The Supreme Court, sitting as the High Court of Justice (H.C.J.), ${ }^{90}$ has received over the years petitions of women - individuals and organisations - who wished to advance and anchor their rights as equal citizens in society. On occasion, the Court has established important legal, egalitarian principles. Here some of the Court's ground-breaking rulings will be highlighted. H.C.J. 104/87 Nevo v. the National Labour Court et al the Court annulled a Jewish Agency provision in the Pension Rules differentiating between employees in accordance with their gender: the retirement age for men was 65 and for women 60 . Justice Shoshana Netanyahu wrote: "It saddens me that in the Israel of our day it was not clear and self-evident that forcing the retirement of a woman from her work at an earlier age than a man constitutes

\footnotetext{
${ }^{85} \mathrm{http}: / /$ www.jewishvirtuallibrary.org/jsource/Politics/PreventionofFamilyViolenceLaw.pdf

${ }^{86}$ E.g., Equal Opportunities in Employment Law (Amendment no. 3), 5755-1995.

${ }^{87}$ Prohibition of Discrimination in Goods, Services and Entrance to Public Places Law, 5761-2000. 88 Prevention of Sexual Harassment Law, 5758 - 1998 , http://www.mfa.gov.il/mfa/aboutisrael/state/law/pages/prevention_of_sexual_harassment_law_57581998.aspx

89 Single-Parent Families Law 5752 - 1992.

90 This is a unique function of the Supreme Court in Israel as the High Court of Justice acts as a court of first and last jurisdiction. It addresses matters where it deems necessary to grant relief in the interest of justice and where the matter is not in the jurisdiction of any other court tribunal.
} 
discrimination". ${ }^{91}$ In H.C.J. 4541/94 Miller v. Minister of Defense the Court accepted a petition of a woman soldier who was refused entry to the pilot's course of the Israel Air Force on the grounds of her gender. ${ }^{92}$ This important precedent clarified that women have the right to fill any role in the army unless compelling reasons are argued against. Gender in itself is not a compelling reason.

In H.C.J. 453/94 Israel Women's Network (IWN) v. Minister of Transportation the Court endorsed the need for equal opportunity and affirmative action. In this case, the Israel Women's Network successfully brought a petition to implement the provisions of a legislative measure introducing a requirement of fair representation of both sexes in appointments to the boards of directors of government companies. ${ }^{93}$ Similarly, in H.C.J. 2671/98 IWN v. Minister of Labor, the petition was for fair representation of women in promotion to the level of deputy director general in the National Insurance Institute. Accepting the petition, the Court set a ground-breaking precedent on the priority of the right to equality in the legal system and, in particular, the issue of affirmative action. ${ }^{94}$

In 1998, the Court in the Shakdiel and Poraz cases established that women are entitled to take part in state administrative bodies even when they are dealing with religious services. In Shakdiel the issue related to the decision of the Minister for Religious Affairs and a Ministerial Committee set up under the Jewish Religious

\footnotetext{
91 H.C.J. 104/87, Nevo v. the National Labour Court et al., (http://ww3.lawschool.cornell.edu/AvonResources/Dr.NaomiNevov.NationalLabourCourt.pdf 92 H.C.J. 4541/94 Miller v. Minister of Defense, http://www.dindayan.com/rulings/94045410.z01.pdf 93 H.C.J. 453/94 IWN v. Minister of Transportation, 48(5) P.D. 501.

94 H.C.J. 2671/98 IWN v. Minister of Labor, 52(3) P.D. 6.
} 
Services Law of $1971^{95}$ to refuse to appoint Leah Shakdiel to serve as an elected member of a local religious services council, on the grounds that she was a woman. ${ }^{96}$ The issue in Poraz was similar: excluding women from public life only because on the basis of gender. Here the Tel Aviv Municipal Council decided not to appoint women to the electoral board for the Tel Aviv municipal rabbi. ${ }^{97}$ Both times an argument was made by the opposition to the appointments that under Jewish Law women may not elect or be elected to public offices. The women petitioned to the Supreme Court to enforce their right of participation and both times their petitions were granted. The Court recognized women's right to equality as a "fundamental principle" of the Israeli legal system.

\section{Inegalitarian Practices in Israel Today}

Women are required to face a number of religious practices that are offensive to their sensibilities and involve coercion, in conflict with the liberal elements of democracy that vouchsafes the rights of individuals. The status of women in personal matters is especially problematic and calls for drastic reform. According to Jewish law, a married woman has no money or property of her own, and she is fully subjugated to her husband. When a wife dies, the husband inherits her belongings, but when the husband dies, his wife does not inherit his belongings. ${ }^{98} \mathrm{~A}$ daughter does not inherit

\footnotetext{
${ }^{95}$ Jewish Religious Services Law (1971), http://www.adalah.org/uploads/oldfiles/Public/files/Discriminatory-Laws-Database/English/29Religious-Jewish-Services-Law-1971.pdf 96 H.C.J. 153/87 Shakdiel v. Minister for Religious Affairs et al. http://ww3.lawschool.cornell.edu/AvonResources/Shakdielv.MinisterofReligiousAffairs.pdf ${ }^{97}$ H.C.J. 953/87 Poraz v. Lahat, Mayor of Tel Aviv et al. 42 (2) PD (1988), 309.

${ }^{98}$ Tractate Bava Batra 111b and Maimonides, Laws of Inheritance, chapter one, halacha eight.
} 
unless there are no sons. It is expected that a certain amount of the father's property be designated for his daughter's dowry and may be claimed from the brother's inheritance..$^{99}$

\section{Divorce}

The establishment of patriarchy is most clearly expressed in the ultimate power of the man not to release his wife from the bonds of marriage. Women are not only passive in this respect; they are also impotent and powerless. Divorce is not a judicial act and may be achieved only in accordance with the husband's wish. In Deuteronomy 24:1 it is written: "A man takes a wife and possesses her. She fails to please him because he finds something obnoxious about her, and he writes her a bill of divorcement, hands it to her and sends her away from his house". From this verse in Deuteronomy Halacha establishes that a Jewish divorce occurs only when a man issues a bill of divorce to his wife (a get). Generally speaking, a woman cannot demand a get nor can she claim her marriage is dead. The get is an exclusive right of the husband. The asymmetry and inequality are clear: A Jewish woman cannot divorce her husband. If the wife refuses her consent, the husband may be able to acquire a rabbinical dispensation to remarryUntil the husband declares that he is willing to 100 .

\footnotetext{
99 Tirzah Meacham, "Legal-Religious Status of the Jewish Female", Jewish Women Encyclopedia, http://jwa.org/encyclopedia/article/legal-religious-status-of-jewish-female

100 P. Shifman, Family Law in Israel (Jerusalem: The Sacher Institute, Hebrew University of Jerusalem, 1984, Hebrew): 178-179. In Tractate Yevamot 112b: "The woman goes out whether or not she wants to, and the man sends her out only if he wants." And Shulchan Aruch, Eben HaEzer, paragraph 119,
} 
divorce his wife, there is no way a woman can be released from marriage. Women who are refused a divorce cannot remarry. ${ }^{101}$

The non-Orthodox Jewish denominaitons are more egalitarian. However, the Reform and Conservative movements are relatively small in size and did not establish themselves yet as part of the Israeli mainstream. ${ }^{102}$ The power greatly lies in the hands of the Orthodoxy. The Jewish religious establishment, the Chief Rabbinate, is solely orthodox and does not open its door and welcome religious diversity. The Orthodoxy rules supreme and dictates the norms and customs of the state.

There are many instances in which husbands refuse to grant their wives a divorce, and then the women cannot remarry or else give birth to legitimate children. These women are called agunot, or chained women. An agunah is a married woman who is unable to live with her husband because of his disappearance, insanity or abandonment while refusing to give her a get (to divorce her), and yet is declared by Jewish law as married. She is chained to an unwanted marriage and unable to remarry until there is clear evidence that the husband is willing to grant her a get or that he is

section six: "He may divorce her against her will." See Daat Emet, "The Status of Women in Halacha", http://www.daatemet.org/articles/article.cfm?article_id=120\&lang=en

${ }^{101}$ Deuteronomy 24:1; Gittin 85a-b. It should be noted that there are Torah principles and requirements incumbent upon a man who can no longer live as a husband with his wife; thus the wife is not totally discounted. A woman can demand a get if her husband develops an unbearable odor or a repulsive illness or injury, if he forsakes Torah, if he does not feed or support her, if he has an impossible angry temper, or if he withholds requisite intimate relationship. See Rabbi Forsythe, Shalom Bayis (Peaceful Marriage) Torah and Family Issues When Considering Divorce, http://www.shemayisrael.com/rabbiforsythe/shalombayis/issues.htm

102 R. Cohen-Almagor, "The Monopoly of Jewish Orthodoxy in Israel and Its Effects on the Governance of Religious Diversity", in Anna Triandafyllidou and Tariq Modood (eds.), More or Less Secularism? European Problems, Asian Lessons (Edinburgh: Edinburgh University Press, forthcoming). 
dead. In Israel there are thousands of women in this situation. ${ }^{103}$ Despite the vast halachic literature on the subject, ${ }^{104}$ many thousands of women in Israel today find themselves chained by recalcitrant husbands. ${ }^{105}$ Ruth Halperin-Kaddari who serves on the United Nations Committee on the Implementation of the Convention on Elimination of Discrimination Against Women (CEDAW) estimated that 100,000 women were put in a situation of blackmail and/or get refusal by their husbands. ${ }^{106}$ This situation calls for a drastic change. The Maharsha, Rabbi Samuel Eidels (15551631) asserted that God blesses his people with peace, "and all her paths are peace" and there will be no peace if the woman is an agunah. ${ }^{107}$ The inbuilt inequality of rights in Jewish law calls for correction and be remedied, and the courts are required to come to women's help. As Maimonides ${ }^{108}$ instructed: "When a man whom the law requires to be compelled to divorce his wife does not desire to divorce her, the court should

${ }^{103}$ Shabtai Bendt, "37 years without a get: the unbearable situation of agunot in Israel", Walla News (1 April 2013, Hebrew), http://news.walla.co.il/?w=/90/2629479

104 Otzar HaPoskim, an encyclopedic work that summarizes the responsa literature to the Even Haezer section of Shulchan Aruch, devotes (in its 1982 edition) no less than eight volumes spanning approximately 1500 pages to this topic alone. Fifteen hundred pages merely summarize the responsa literature to the subject of Agunah. See Meir Goldberg, Moral problems in Halacha: Women, http://truetorah.blogspot.com/2013/07/moral-problems-in-halacha-women-with.html. See also Chaim Grade's moving novel, The Agunah (Indianapolis, IN: Bobbs-Merrill, 1974).

105 Rivka Luvich, "When religious courts play with data", Ynet (24 January 2008), http://www.ynet.co.il/articles/0,7340,L-3497422,00.html (Hebrew).

${ }^{106}$ Ruth Halperin-Kaddari and Tamar Adelstein-Zekback, Pi Project -- Supervision Enforcement and Implementation of Family Law in Israel (Ramat Gan: The Rackman Center for the Advancement of the Status of Women, 2011): 21 (Hebrew).

107 Rabbi Samuel Eidels, Chiddushei Aggadot.

108 Moses Ben Maimon, also called Rambam (30 March 1135 - 13 December 1204) was a Jewish philosopher, jurist and physician. He is considered the foremost intellectual figure of medieval Judaism and one of the chief authoritative codifications of Jewish law and ethics. 
have him beaten until he consents, at which time they should have a get written. The get is acceptable. This applies at all times and in all places". ${ }^{109}$

The Rabbinic Courts have the ability to sanction those men. The 1953 Rabbinic Courts Jurisdiction Law (Marriage and Divorce) provides the courts with the ability to compel a divorce by jailing recalcitrant husbands. ${ }^{110}$ Under the 1995 Rabbinical Courts Law (Enforcement of Divorce Judgments) (Emergency Order), courts are able to confiscate passports, freeze bank accounts, suspend drivers' licenses, prohibit the appointment or election to or the holding of public office, restrict work in a profession that is regulated by law, prohibit operation of a business that requires a license, and imprison recalcitrant individuals to compel compliance. ${ }^{111}$ These are significant sanctions, but the Rabbinic Courts rarely sanction those refusing men. ${ }^{112}$ When the husband refuses a divorce and insists on shlom bayit (literally means, peace in the home), the courts tend to seek reconciliation and push to maintain the marriage.

Divorce, of course, is a significant decision and should not be taken lightly. Attempts to reconcile and restore partnership and friendship in marriage should be made. The courts need to probe and ponder the reasons for the divorce petition, and

109 Maimonides, Laws of 2:20,

http://www.chabad.org/library/article_cdo/aid/957707/jewish/Chapter-Two.htm

${ }^{110}$ Rabbinic Courts Jurisdiction Law (Marriage and Divorce), 5713-1953, section 6: "Where a Rabbinical Court, by final judgment, has ordered that a husband be compelled to grant his wife a letter of divorce or that a wife be compelled to accept a letter of divorce from her husband, a District Court may, upon expiration of six months from the day of the making of the order, on the application of the Attorney General, compel compliance with the order by imprisonment".

${ }^{111}$ Rabbinical Courts Law (Enforcement of Divorce Judgments), 5755-1995, sections 2 and 3; Jewish Law Watch, The Agunah Dilemma (Jerusalem: The Schechter Institute of Jewish Studies, 2000): 8-9. 112 "chained" woman, hayarkon70 news, http://www.youtube.com/watch?v=eTayig3piiY (Hebrew); Yehiel S. Kaplan, "Enforcement of Divorce Judgments in Jewish Courts in Israel: The Interaction Between Religious and Constitutional Law", Middle East Law and Governance, Vol. 4 (2012): 1-68, at 3. 
whether the decision is reversible in good faith. Sometimes peace in the house can be restored if there is good will on both parties, and trust can be rebuilt. But sometimes peace and trust are not achievable. Sometimes marriages are broken beyond repair. Then the courts are called to act and impose sanctions against the recalcitrant spouse, effectively husbands, because men have the option to obtain a dispensation to contract an additional marriage without their wives' blessing while women do not have this option. Against those men, the courts should employ first the least drastic sanctions, but if the husbands remain obstinate then the courts need to increase the severity of the sanctions and demonstrate no less stubbornness that would match the husbands' obstinacy and compel the recalcitrant men to grant their wives the desired get. ${ }^{113}$

The husband's refusal to divorce his wife results not only in the wife's inability to remarry but also in strict restrictions on her freedom to set up new family life. Should she have a sexual relationship with another man, she is considered a rebellious wife and may lose her rights to child custody and spousal maintenance although she remains married; she will also be prohibited from marrying her lover if at any future time her husband dies or releases her from the marriage. Should she, while still married, have a child from another man, that child will be considered a "mamzer". As explained, "mamzer" is a form of bastardy applicable only to the children of adultery by a woman. ${ }^{114}$ The "mamzer" will not be eligible to marry under Jewish law except if

\footnotetext{
${ }^{113}$ Rabbinic Courts Jurisdiction Law (Marriage and Divorce), 5713-1953, section 6: "Where a Rabbinical Court, by final judgment, has ordered that a husband be compelled to grant his wife a letter of divorce or that a wife be compelled to accept a letter of divorce from her husband, a District Court may, upon expiration of six months from the day of the making of the order, on the application of the Attorney General, compel compliance with the order by imprisonment".

114 Mamzerim (bastards) cannot marry within the Jewish community: Deuteronomy 23:3; Shulhan Arukh, Even HaEzer.
} 
he/she marries another "mamzer" or a convert to Judaism In contrast, for men ${ }^{115}$. whose wives refuse to agree to the divorce there is no problem of "mamzerut" and there are ways in which the husband may acquire the right to remarry without a divorce. ${ }^{116}$ The gender inequality is built in the Jewish tradition. Originally polygamy was allowed under biblical law: a man was allowed to marry more than one woman while a woman was forbidden to marry more than one man. ${ }^{117}$ Hence multiple sexual associations of a married man are not repugnant in Jewish law in the way that those of a married woman are.

\section{Exclusion and segregation}

In recent years we witness more and more manifestations of segregation of women. Discrimination takes place in public places and in public transportation. We observe attempts to control women's conduct, dress code and freedoms in ways that contravene Israel's commitment to gender equality. Efforts are made not only to segregate women but also to exclude them altogether from public spaces. Women are discriminated against in cemeteries, in public events even when they are statesponsored, in health clinics, and in public streets where signposts direct women to

\footnotetext{
115 Frances Raday, "Religion, Multiculturalism and Equality: The Israeli Case", Israel Yearbook on Human Rights, Vol. 25 (1995): 193-241; R. Cohen-Almagor, "Israeli Democracy, Religion and the Practice of Halizah in Jewish Law", UCLA Women's Law Journal, Vol. 11, No. 1 (Fall/Winter 2000): 4565. For further discussion on the status of women, see Moshe David Herr, "Retreat in the Position of Women in Halacha", New Directions, Vol. 27 (November-December 2012): 61-81 (Hebrew).

${ }^{116}$ Frances Raday, "Women's Rights", in R. Cohen-Almagor (ed.), Israeli Democracy at the Crossroads (London: Routledge, 2005): 81; Eliav Shochatman, "Woman's Status in the Law of Marriage and Divorce", in Frances Raday, Carmel Shalev and Michal Liban Kooby (eds.), Women's Status in Israeli Law and Society (Tel-Aviv: Schocken, 1995): 380 (Hebrew).

${ }^{117}$ Eben HaEzer 1, paragraph nine: "A man marries several women if he can maintain them, but in any case the Sages suggested that a man not marry more than four wives so that each will have her turn every month".
} 
seek alternative paths or to adhere to a strict dress code if they wish to pass through certain neighbourhoods. Women are prevented to give eulogies in funeral ceremonies. Girls are banned from dancing in public gatherings and female soldiers are denied singing in official ceremonies. ${ }^{118}$ Pictures of women who appear on advertisements, political posters and historical photographs are vandalized and/or removed. ${ }^{119}$ On Meir children's Internet channel, which is popular among the national Haredi sector, girls and women do not exist. ${ }^{120}$ The message is loud and clear: it is a man's world. One local radio station, "Kol Barama", prohibits the broadcasting of women voices and hiring women presenters. ${ }^{121}$ The Attorney General conclusively argued that the radio station cannot eliminate women from public space. The station's policy of restricting the possibility of women to participate in all the broadcasted programs violates the basic rights to human dignity and liberty, equality, and freedom of expression. Prohibiting a woman from expressing herself and being heard merely because she is a woman is a grave example of gender discrimination. It assumes that a woman has no right to be heard like any other person. ${ }^{122}$

In the very religious neighbourhoods, Mehadrin public bus service operates in accordance with strict Orthodox codes. This public service started in 1997 with two

\footnotetext{
${ }^{118}$ Ruth Halperin-Kaddari, "Women in Israel: From Illusion of Equality to Exclusion", The Jofa Journal, Vol. X, Issue 2 (Fall 2012): 3; Roni Hazon Weiss, "The Campaign Against the Exclusion of Women from Public Spaces”, Ibid, pp. 34-36; Orly Erez-Likhovski and Riki Shapira-Rosenberg, Excluded, for God's Sake (Jerusalem: Israel Religious Action Center and Israel Movement for Reform and Progressive Judaism, 2013-2014): 20.

119 Orly Erez-Likhovski and Riki Shapira-Rosenberg, Excluded, for God's Sake: 64-71.

120 Tamar Rotem, "Channel Meir presents: About boys and about boys", Haaretz (25 May 2013) (Hebrew), http://www.haaretz.co.il/gallery/kids/.premium-1.2029111

${ }^{121}$ Report of the Committee Established to Examine Women Exclusion in the Public Place, Submitted to the Legal Advisor to the Government (Jerusalem, 7 March 2013, Hebrew).

122 Orly Erez-Likhovski and Riki Shapira-Rosenberg, Excluded, for God's Sake: 55.
} 
bus lines in Jerusalem and Bnei Brak, two cities with large religious populations, and with time it grew in size and volume. By 2007, there were some thirty bus lines with segregated seating for men and women. Women are expected to sit at the back. This publicly funded transportation system is quite attractive for the Haredi population because the bus lines are faster (express) than the regular bus lines, and the fares are substantially cheaper. However, women who resist the segregation rules might be subjected to harassment and physical abuse.

While religious people may operate their own public transportation in a way that suits their conception of the good, this should be done in a way that dignifies both genders. Moreover, there were reports that buses skip certain stops where non-Haredi women are liable to board the bus. ${ }^{123}$

Finding a balance between egalitarian principles and Jewish-Orthodox dictates is not an easy task. In January 2011, the High Court of Justice ruled that gender segregation was unlawful but at the same time the Court ruling allowed the continuation of gender separation in public buses on a strictly "voluntary basis", on the pretext of respecting multiculturalism and the right of people to practice their religious norms as they see appropriate. Justice Elyakim Rubinstein held that along with the desire to ensure that the seating arrangements on the buses would be entirely voluntary, flexibility should be enabled for those passengers who seek to adopt gender separation among themselves provided that it does not become an instrument for harming women. ${ }^{124}$ In practice, however, women who object to this "voluntary segregation" are often subjected to coercive segregation, facilitated by abuse,

\footnotetext{
123 Ibid: 16.

124 H.C.J. 746/07, Naomi Ragen v. Ministry of Transport (5 January 2011), para. 38.
} 
harassment and use of force. ${ }^{125} \mathrm{~A}$ recent report recorded derogatory and violent incidents in which women who refused to abide by the discriminatory dictates were attacked and humiliated. These women were of different religious persuasions, including Haredi. ${ }^{126}$ Furthermore, a pertinent distinction is between internalized coercion and designated coercion. Internalized coercion relates to the system of explanation, propaganda, education and manipulation to which members of religious groups are subjected, which prevents them from realizing that they are being coerced to follow a certain conception that denies them basic rights. Designated coercion is individualistic in nature, aimed at a certain individuals who rebel against the discriminatory norm. Unlike the internalized coercion it is not concerned with machinery aiming to convince the entire religious group of an irrefutable truth; instead it is designed to exert pressure on uncertain, "confused" individuals so as to bring them back to their community. ${ }^{127}$ The majority of Haredi women accept gender segregation and have no problem sitting in the back of the bus, seeing this as a suitable arrangement. However, some religious women resent this arrangement. They do not necessarily object to separate them from men but they do not see why the men should be in the front while they are seated in the back of the bus. These women are opposed to being second-citizens in their own

${ }^{125}$ H.C.J. 5079/97 Israel's Women Network v. Minister of Transport; H.C.J. 746/07, Naomi Ragen v. The Ministry of Transportation (5 January 2011); Noya Rimalt, "Swinging Doors", In Open Doors, Vol. 43 (March-April 2012): 48-49 (Hebrew); Miriam Feldheim, "Balancing Women's Rights and Religious Rights: The Issue of Bus Segregation", Shofar, Vol. 31(2) (2013): 73-94; Riki Shapira, "Giving Voice to Silenced Women: Kolech's Actions on Mehadrin Bus Lines", The Jofa Journal, Vol. X, Issue 2 (Fall 2012): 30-32; Ruth Halperin-Kaddari, "Women, Religion and Multiculturalism in Israel", UCLA J. Int'l L. \& Foreign Affairs, Vol. 5 (2000-2001): 339, 362-364.

126 Orly Erez-Likhovski and Riki Shapira-Rosenberg, Excluded, for God's Sake: 12-15, 17, 84.

${ }^{127}$ R. Cohen-Almagor, "On Compromise and Coercion", Ratio Juris, Vol. 19, No. 4 (2006): 434-455. 
community. ${ }^{128}$ Against these women, the Haredi establishment utilises designated coercion to force them "to see the light" and understand the benefits of discriminatory segregation. ${ }^{129}$

This form of designated coercion is never justified and the state is warranted to interfere in the name of justice and equality. Moreover, as these buses are public, secular women are free to use them and they are not by-product of the said system of explanation, propaganda, education and manipulation. These women behave on these buses as they do on any public bus: they would sit on any available seat notwithstanding its location on the bus. They do not think that someone else's religious beliefs should be an imposition on their own set of beliefs.

Another area of contention concerns the Wailing Wall, the Kotel. Since 1989, a group called Women of the Wall is fighting for the introduction of a new, pluralistic and equal section of the Wailing Wall, which is one of the holiest place for Jewish prayers. ${ }^{130}$ Unlike the current men and women's prayer sections, they demand that this section should not be administered by the orthodox Rabbi of the Kotel. The pluralistic section would be governed under the auspices of a group of leaders from all Jewish denominations, with fair representation for women. The mission of Women of the Wall is to achieve the social and legal recognition of their right, as women, to wear prayer shawls (tallit), pray, and read from the Torah collectively and out loud at

\footnotetext{
${ }^{128}$ Kobi Nachshoni, "Poll: $80 \%$ for core obligation, 63\% for Shabbat transportation”, Ynet (28 September 2011) (Hebrew).

129 In his comments, Lester Grabbe said that this reminds him of racial segregation in Southern United States which was declared unconstitutional. See Michael J. Klarman, From Jim Crow to Civil Rights: The Supreme Court and the Struggle for Racial Equality (NY: Oxford University Press, 2006).

130 The Wall, known as the Western Wall and the Wailing Wall is the only structure remaining from the Holy Temple, rebuilt in glorious style and splendour by King Herod, and destroyed by the Romans in $70 \mathrm{AD}$.
} 
the Western Wall. ${ }^{131}$ As the Kotel is the most unsuitable place in the world to wage religious rivalries, a compromise needs to be found so all Jews, notwithstanding their interpretations of Halacha, will be able to pray freely in accordance with their beliefs. Instead, these women were verbally and physically attacked by men who think that the "defiant" women overstep their assigned boundaries.

The case was considered by the Supreme Court several times but divisions within the Court prevented the raising of a clear voice in support of women's equality in this delicate religious affair. In the final hearing with an expanded panel of nine justices, the Court held that the Women of the Wall were entitled to pray in the manner of their choice in the Western Wall compound but in order to prevent injury to the sensitivities of other worshippers, the Court suggested that the government should make arrangements for them in another prayer area at an adjacent site called Robinson's Arch. The Woman of the Wall were opposed to this proposal as they wish to pray in the manner they see appropriate at the women section, adjacent to the men section, and not some hundreds of meters away from the Western Wall. ${ }^{132}$ At the time of writing, the Israeli government passed a resolution that authorised the construction of a new plaza built where men and women can pray together at the Wailing Wall in

\footnotetext{
131 Women of the Wall, http://womenofthewall.org.il/about/faq/; Rivka Haut, "Women of the Wall: Fighting for the Right to Pray", The Jofa Journal, Vol. X, Issue 2 (Fall 2012): 9-10; Frances Raday, "Claiming Equal Religious Personhood: Women of The Wall's Constitutional Saga", in W. Brugger and M. Karayanni (eds.), Religion in the Public Sphere, a Comparative Analysis of German, Israeli, American and International Law (Berlin: Max Plank, 2007): 255-98.

132 H.C.J. 1025/89, 955/89, 699/89 Anat Hoffman v. The Jerusalem Municipality and Others, P.D. 48(1), 678; H.C.J. 257/89 Anat Hoffman v. Commissioner of the Western Wall, P.D. 48(2) 265; H.C.J. 3358/95 Anat Hoffman v. Director General of Prime Minister's Office, P.D. 54(2) 345; H.C.J. 4128/00 Director General of Prime Minister's Office v. Anat Hoffman, P.D. 57(3) 289; R. Cohen-Almagor, "Israel and International Human Rights", in Frederick P. Forsythe (ed.), Encyclopedia of Human Rights (New York: Oxford University Press, 2009), Vol. 3: 247-257; Frances Raday, "Women of the Wall”, Jewish Women's Archive, http://jwa.org/encyclopedia/article/women-of-wall
} 
Jerusalem's Old City. Two other sections will remain segregated by gender. This historic decision means that, for the first time ever, men and women will be able to pray side-by-side at Judaism's holiest site. ${ }^{133}$ However, the Orthodox and ultraOrthodox immediately voiced their protest against the decision, saying that it only create conflict and dispute.

The feminist challenge to Orthodoxy is hard as these women are fighting against the establishment. On each and every issue that is regarded as "man's domain", be it praying rituals, membership in religious bodies or the ordination of women rabbis, women are facing strong resistance as they challenge intricate and complex web of entrenched norms that for the Orthodoxy define Jewish identity. ${ }^{134}$ While we can discern some progress in religious gender equality in education, prayer rituals, public leadership and domestic family abuse, the success is modest. Powerful religious sectors still do not appreciate women creativity, spirituality, intelligence and engagement, and wish to minimize their role in society.

In March 2013, the Attorney General issued a scathing report against the phenomenon of gender segregation and the exclusion of women. Its unequivocal conclusion was that these discriminatory practices undermine the very foundations of Israeli democracy which recognizes the inherent value of every human being. Tolerance must be shown toward lifestyles of different communities. Exclusion of

\footnotetext{
${ }^{133}$ Paul Goldman, "Israel to Build Area for Men, Women to Pray Together at Wailing Wall", NBC News (1 February 2016 ), http://www.nbcnews.com/news/world/israel-build-area-men-women-pray-togetherwailing-wall-n508551

134 Leah Shakdiel, "Women of the Wall: Radical Feminism as an Opportunity for a New Discourse in Israel", Journal of Israeli History, Vol. 21(1) (2002): 126-163; Yael Israel-Cohen, Between Feminism and Orthodox Judaism (Leiden: Brill, 2015): 49-78; Irit Koren, "Religious Feminism in Israel: A Revolution in Process" AJS (no date), http://www.bjpa.org/publications/downloadFile.cfm?FileID=2623. For further discussion, see Valerie Bryson, Feminist Political Theory (London: Palgrave, 2016): 268297.
} 
women as equal participants in civil life is unacceptable. The report also dismissed the Haredi argument that maintaining segregated arrangements in the public sphere is required for the preservation of its unique character. ${ }^{135}$ The Attorney General instructed municipalities, religious services, bus companies, health clinics and public institutions to take active steps to ensure gender equality. While some services have changed their practices and stopped gender segregation and discrimination, others are slow to respond. ${ }^{136}$ This divide between what the law of the state says, and the practice of religious communities harms women and undermines Israeli democracy.

\section{Conclusion}

Jewish law challenges the foundations of liberal democracy (liberty, equality, tolerance, justice). Religion undermines its attractiveness when it is unyielding and coercive. Persuasion and explanation are constructive. Coercion is destructive. Religion should not alienate itself from people but rather act as unifying glue between people. At present, however, Halacha discriminates against women. The blessing recited by men each morning thanking God for having "made me not a woman" is symptomatic of a chauvinistic attitude toward women, intentionally cultivated by the religious system as a whole. ${ }^{137}$ To assure an equal status for women, it is time to translate the words of the Declaration of Independence into conduct and to strive to achieve real equality between men and women and to secure civic and human rights for all. There is an unhealthy discrepancy between words and deeds, between the

\footnotetext{
135 Orly Erez-Likhovski and Riki Shapira-Rosenberg, Excluded, for God's Sake: 7-8.

136 Ibid., pp. 23-26, 29-31, 33-41, 51-58, 75-81,

137 Saul J. Berman, “The Status of Women in Halakhic Judaism”, Tradition, Vol. 14:2 (1973),

http://www.lookstein.org/articles/status_of_women.htm
} 
language that invokes the values of liberty, justice and peace and their application in everyday life.

Israel should also incorporate the International Covenant of Civil and Political Rights, the International Covenant of Economic, Social and Cultural Rights, and the International Convention for Elimination of All Forms of Discrimination against Women into domestic law and make them enforceable without reservations. Mere ratification of these and other important human rights conventions (mentioned above) without incorporation into law is simply not sufficient for protecting women's rights.

The Reform and Conservative movements should have the same status enjoyed by the Orthodoxy. Conservative and Reform institutions and synagogues should receive state funding in the same way that Orthodox institutions do. The Chief Rabbinate should include representatives of the two movements.

The Orthodox Rabbinate should not enjoy monopoly on issues regarding personal status, particularly marriage and divorce. This coercive monopoly causes disunity and hostility between Israelis and also between Israel and Jews abroad, many of whom are not Orthodox.

Civil marriages should be recognised in Israel. Israeli couples who were married in civil ceremonies abroad should be able to divorce in civil courts. Presently they are able to get legally divorced only in Israeli rabbinical courts. Respect for religious diversity and for individual preferences is required. People, if they so desire, may involve rabbinate and other religious institutions in their private lives. But this option should be left to them. If people wish to have secular ceremonies then they should have the ability to conduct them and not to be forced to undergo practices which mean very little to them, if anything. The state should have as little as possible say in family, intimate affairs. What is needed is a deliberative process involving all people, secular 
and those who are affiliated with different religious denominations, aiming to reach an acceptable compromise that is egalitarian and respectful of diverse ways of life.

Ruth Halperin-Kaddari unequivocally states that Israeli women are the only women in the Western world who are still subjected to discriminatory laws in the most personal and critical spheres of private life, marriage and divorce. They are also the only women in the Western world who are completely barred from fulfilling official judicial roles in national religious courts. ${ }^{138}$ This situation undermines the democratic foundations of Israel and constitutes gross violation of basic human rights of some fifty percent of the Israeli population.

A recent poll shows that $75 \%$ of the Jewish public supports the introduction of civil divorce in Israel. Dr Susan Weiss, Director of the Center for Women's Justice rightly said that the right to marry and the right to divorce are fundamental human rights. Weiss maintained: "Israel's imposition of Torah law on its citizens is a violation of human rights, and it unnecessarily causes more women to become agunot. Officially adopting civil marriage and divorce in Israel will significantly reduce the number chained women, and would be the first and necessary step towards a comprehensive solution of this terrible phenomenon". ${ }^{139}$

The preservation of the Jewish character of the state should not entail coercion of women. Coercion is foreign to our natural sentiments and desires to lead our lives free as possible from alien restraints and impediments. Israel is required to secure basic rights and liberties to all its citizens, notwithstanding gender, religion, nationality, race or sexual orientation. The very fact that I am in need to reiterate this obvious

\footnotetext{
138 Ruth Halperin-Kaddari, "Women in Israel: From Illusion of Equality to Exclusion": 4.

139 Hiddush News, "75\% support introduction of civil divorce in Israel”, Hiddush (22 March 2016).
} 
Raphael Cohen-Almagor

statement in itself manifests just how problematic gender equality is in Israeli democracy. This situation is unjust and calls for constructive remedies.

\section{Raphael Cohen-Almagor}

